\title{
Metabotropic Glutamate Receptor Protein Expression in the Prefrontal Cortex and Striatum in Schizophrenia
}

\author{
DAYA S. GUPTA, ${ }^{1}$ ROBERT E. McCULLUMSMITH, ${ }^{1 *}$ MONICA BENEYTO, ${ }^{1}$ VAHRAM HAROUTUNIAN, ${ }^{2}$ \\ KENNETH L. DAVIS, ${ }^{2}$ AND JAMES H. MEADOR-WOODRUFF ${ }^{1}$ \\ ${ }^{1}$ Department of Psychiatry and Mental Health Research Institute, University of Michigan \\ Medical School, Ann Arbor, Michigan \\ ${ }^{2}$ Department of Psychiatry, Mount Sinai School of Medicine, New York, New York
}

\begin{abstract}
We investigated the expression of metabotropic glutamate receptors (mGluR) in the prefrontal cortex (PFC) and striatum in schizophrenia. mGluRs modulate the release and reuptake of synaptic glutamate and mediate some molecular correlates of neuroplasticity, including long-term potentiation. The mGluRs are expressed widely in the PFC and striatum, regions often implicated in the pathophysiology of schizophrenia. Thus, we hypothesized that abnormal expression of mGluRs might contribute to glutamatergic dysfunction observed in the PFC and striatum in schizophrenia. Accordingly, we measured the expression of metabotropic glutamate receptors (mGluRs) in Brodmann areas 9, 11, 32, and 46 in the prefrontal cortex (PFC) and the caudate, putamen, and nucleus accumbens in schizophrenia (16 cases, 9 controls) by Western blot analysis. We found an increase in the expression of mGluR1a and mGluR2/3 immunoreactivity in the PFC in schizophrenia, while no changes in the expression of mGluR4a or mGluR5 were detected in this region. In the striatum we found no changes in the expression of any of the mGluRs studied. These results suggest that alterations of mGluR1a and mGluR2/3 expression in the PFC may contribute to the pathophysiology of schizophrenia, and support targeting these receptors for the generation of novel treatment modalities for this disabling illness. Synapse 57:123131, 2005. ๑ 2005 Wiley-Liss, Inc.
\end{abstract}

KEY WORDS mGluR; Western blot; postmortem brain; human; neuroanatomy; immunoreactivity

\section{INTRODUCTION}

Converging lines of evidence implicate glutamatergic abnormalities in schizophrenia (Clinton et al., 2003; Clinton and Meador-Woodruff, 2003; Goff and Coyle, 2001; Kegeles et al., 2000; Meador-Woodruff et al., 2001b, 2003; Meador-Woodruff and Healy, 2000; Mueller et al., 2004; Mueller and Meador-Woodruff, 2004; Theberge et al., 2002). While pharmacological data suggest NMDA receptor dysfunction, other studies and theoretical considerations indicate that other receptors associated with glutamatergic transmission may be abnormal in this illness. One such family of molecules, the metabotropic glutamate receptors (mGluRs), are G-protein-linked receptors that facilitate myriad synaptic functions, including regulation of synaptic glutamate levels and long-term potentiation. Given these critical roles in glutamate neurotransmission and evidence implicating glutamatergic dysfunction in schizophrenia, we investigated mGluR expression in schizophrenia.
Eight mGluRs have been identified and grouped into three categories based on sequence homology, second messenger coupling, and agonist specificity (Nakanishi, 1992, 1994; Nakanishi et al., 1998; Pin and Duvoisin, 1995). mGluR1 (mGluR1a-d), mGluR4 ( $a$ and b), and mGluR5 ( $a$ and b) may be alternatively spliced at the c-terminus (Conn and Pin, 1997). Group I mGluRs (mGluR1 and mGluR5) are positively coupled to phosphoinositide hydrolysis via phospholipase $\mathrm{C}$ activation and typically increase cellular excitability by increasing depolarization (Hubert et al., 2001). Group II (mGluR2 and 3) and group III

Contract grant sponsor: VA Merit Review; Contract grant numbers: MH53327 (to J H M W.); MH064673 (to VH); MH66392 (to K L.D.); Contract grant sponsor: Pfizer Postdoctoral Fellowship (to R.E.M.)

*Correspondence to: Robert McCullumsmith, M.D., Ph.D., Mental Health Research Institute and Department of Psychiatry, University of Michigan, 205 Zina Pitcher Place, Ann Arbor, MI 48109-0720. E-mail: smithrob@umich.edu

Received 10 March 2005; Accepted 22 April 2005

DOI 10.1002/syn.20164

Published online in Wiley InterScience (www.interscience.wiley.com). 
mGluRs (mGluR 4, 6, 7, and 8) are negatively coupled to adenylate cyclase and their activation results in reduced neurotransmitter release (Hubert et al., 2001). Group II and group III mGluRs are differentiated based on their responses to the agonists trans-1aminocyclopentane-1, 3-dicarboxylate and L-2-amino4-phosphonobutyrate (Mateos et al., 2000).

mGluRs are found throughout the brain, including unique patterns of expression in the prefrontal cortex, thalamus, and striatum. Single cell polymerase chain reaction (PCR) studies in rat have found that group I mGluRs are the most abundantly expressed of the mGluRs in both pyramidal neurons and interneurons in neocortex (Cauli et al., 2000). mGluR2 and mGluR3 share very high sequence homology such that antibodies raised for one typically crossreact with the other. Presynaptic mGluR2 and mGluR3 (mGluR2/3) immunoreactivity has been detected at asymmetric synapses in all cortical layers (Muly et al., 2003; Petralia et al., 1996). In the striatum, mGluR1a and mGluR5 are expressed by different subpopulations of interneurons and projection neurons (Tallaksen-Greene et al., 1998). The group III mGluRs, mGluR4 and mGluR7, are expressed at asymmetric synapses in the striatum (Bradley et al., 1999a,b; Kosinski et al., 1999).

Several studies have examined mGluR mRNA or protein expression in schizophrenia. In general, few significant changes in mGluR gene expression in schizophrenia have been reported. mGluR5 mRNA was increased in the pyramidal cell layers of Brodmann area 11, but decreased in the parahippocampal gyrus in a different study (Crook et al., 2002; Ohnuma et al., 1998, 2000). In contrast, more robust findings have emerged from linkage studies suggesting the involvement of both mGluR3 and mGluR5 in schizophrenia (Chen et al., 2005; Devon et al., 2001; Egan et al., 2004; Fujii et al., 2003). Other genetic studies have also suggested the involvement of RGS4, which regulates the activity of mGluR1 and mGluR5, in the pathophysiology of this illness (Chowdari et al., 2002).

The prefrontal cortex (PFC) has emerged as the dominant site of abnormal brain function in schizophrenia based on several lines of evidence as reviewed elsewhere (Bunney and Bunney, 2000; Weinberger et al., 2001). Similarly, different regions of the neostriatum, including the caudate nucleus, putamen, and nucleus accumbens, are abnormal in schizophrenia based on morphological, physiological, and neuropsychological findings (Braff and Geyer, 1990; Dean and Hussain, 2001; Healy et al., 1998; Hsiao et al., 2003; McCullumsmith and Meador-Woodruff, 2002; Meador-Woodruff et al., 1996, 2001b; Noga et al., 1997). The PFC and the striatum have dense glutamatergic innervations, including cortical glutamatergic projections to the striatum, and the mGluRs have a central role in the regulation of glutamate transmission in these regions. Based on the critical role of mGluRs in glutamatergic neurotransmission and evidence implicating the PFC and striatum in schizophrenia, we examined expression of mGluR1a, 2/3, 4a, and 5 in Brodmann areas (BA) 9, 11, 32, and 46 of the PFC, and in the caudate, putamen, and nucleus accumbens in subjects with schizophrenia and a comparison group.

\section{MATERIALS AND METHODS Acquisition and processing of the postmortem brain tissue}

The subjects were from the Mount Sinai Medical Center and Bronx Veterans Administration Medical Center. Subjects were diagnosed with schizophrenia if the following criteria were fulfilled: 1) the presence of schizophrenic symptoms could be documented before age $40 ; 2$ ) the medical records contained evidence of psychotic symptoms and at least 10 years of psychiatric hospitalization with a diagnosis of schizophrenia; 3) the DSM-III-R diagnosis of schizophrenia was agreed upon by two experienced clinicians; 4) the neuropathologic examination did not reveal Alzheimer's disease or other neurodegenerative disorders. Characteristics of the subjects are summarized in Table I. Brains obtained at autopsy were prepared by slicing one hemisphere into $0.5-0.8-\mathrm{cm}$ coronal slabs which were snap-frozen in liquid nitrogen-cooled isopentane. Brodmann areas were defined by sulcogyral position and $-80^{\circ} \mathrm{C}$ storage time ranged from $2-3$ years.

\section{Antibodies}

Commercially available antibodies used in these studies are listed in Table II. These antibodies have previously been used for Western blot experiments and were demonstrated to not crossreact with other mGluRs (Aronica et al., 2000, 2003; Gill et al., 1999).

\section{Western blot analysis}

We have previously utilized sections from the tissue blocks for this cohort in several in situ hybridization and receptor binding studies (Healy et al., 1998; Meador-Woodruff et al., 1996, 1997, 2001a). After sectioning for the aforementioned studies, the tissue remaining on the blocks was stored at $-80^{\circ} \mathrm{C}$.

Prior to dissection of tissue from the blocks for Western blot analysis, we Nissl-stained the last section to permit further identification and confirmation of the anatomical region harvested for each subject. For the nucleus accumbens, putamen, caudate, and BAs, 9 (superior frontal gyrus), 11 (orbital gyrus, gyrus rectus), 32/24 (cingulate gyrus), and 46 (dorsolateral prefrontal cortex), $\sim 1 \mathrm{~cm}^{3}$ of tissue was dis- 
TABLE I. Subject characteristics

\begin{tabular}{|c|c|c|c|c|c|c|}
\hline Diagnosis & Age (years) & Gender & $\mathrm{Rx}$ & PMI (minutes) & $\mathrm{pH}$ & Cause of death \\
\hline CTL & 88 & M & $\mathrm{N}$ & 285 & 5.9 & Cardiac \\
\hline CTL & 86 & $\mathrm{~F}$ & $\mathrm{~N}$ & 280 & 6.5 & Unknown \\
\hline CTL & 70 & M & $\mathrm{N}$ & 482 & 6.0 & Pulmonary hypertension \\
\hline CTL & 55 & M & $\mathrm{N}$ & 600 & 5.7 & Cancer \\
\hline CTL & 79 & $\mathrm{~F}$ & $\mathrm{~N}$ & 181 & 5.5 & Cardiopulmonary failure \\
\hline CTL & 96 & $\mathrm{~F}$ & $\mathrm{~N}$ & 195 & 6.7 & Cardiopulmonary failure \\
\hline CTL & 90 & $\mathrm{~F}$ & $\mathrm{~N}$ & 250 & 6.0 & Cardiopulmonary failure \\
\hline CTL & 74 & $\mathrm{~F}$ & $\mathrm{~N}$ & 180 & 6.0 & Cardiopulmonary failure \\
\hline CTL & 98 & $\mathrm{~F}$ & $\mathrm{~N}$ & 85 & 6.6 & Cardiopulmonary failure \\
\hline & $77 \pm 17$ & $3 \mathrm{M} / 6 \mathrm{~F}$ & & $282 \pm 161$ & $6.1 \pm 0.4$ & \\
\hline $\mathrm{SCZ}$ & 54 & M & $\mathrm{Y}$ & 490 & 6.0 & Acute myelocytic leukemia \\
\hline SCZ & 61 & M & $\mathrm{Y}$ & 212 & 6.5 & Cardiopulmonary failure \\
\hline SCZ & 84 & M & $\mathrm{Y}$ & 372 & 6.5 & Cardiopulmonary failure \\
\hline $\mathrm{SCZ}$ & 69 & M & $\mathrm{Y}$ & 270 & 6.4 & $\begin{array}{l}\text { Cardiac infarction, renal } \\
\text { failure }\end{array}$ \\
\hline SCZ & 76 & $\mathrm{~F}$ & $\mathrm{Y}$ & 510 & 6.1 & $\begin{array}{l}\text { Cardiopulmonary failure, } \\
\text { cancer }\end{array}$ \\
\hline $\mathrm{SCZ}$ & 75 & $\mathrm{~F}$ & $\mathrm{Y}$ & 334 & 6.8 & Cardiopulmonary failure \\
\hline $\mathrm{SCZ}$ & 63 & M & $\mathrm{Y}$ & 372 & 5.9 & Cardiopulmonary failure \\
\hline $\mathrm{SCZ}$ & 69 & $\mathrm{~F}$ & $\mathrm{Y}$ & 820 & 6.2 & Cardiopulmonary failure \\
\hline SCZ & 87 & M & $\mathrm{Y}$ & 670 & 6.5 & Cardiopulmonary failure \\
\hline $\mathrm{SCZ}$ & 68 & M & $\mathrm{Y}$ & 335 & 6.8 & Cardiopulmonary failure \\
\hline SCZ & 64 & $\mathrm{~F}$ & $\mathrm{Y}$ & 392 & 6.6 & Cardiopulmonary failure \\
\hline SCZ & 86 & $\mathrm{~F}$ & $\mathrm{Y}$ & 415 & 5.8 & Respiratory, renal failure \\
\hline $\mathrm{SCZ}$ & 86 & $\mathrm{~F}$ & $\mathrm{~N}$ & 330 & 6.2 & Cardiac, pneumonia \\
\hline $\mathrm{SCZ}$ & 72 & M & $\mathrm{N}$ & 1235 & 6.6 & Cardiopulmonary failure \\
\hline SCZ & 65 & $\mathrm{~F}$ & $\mathrm{~N}$ & 350 & 5.9 & Cardiopulmonary failure \\
\hline \multirow[t]{2}{*}{ SCZ } & 79 & $\mathrm{~F}$ & $\mathrm{~N}$ & 1225 & 7.1 & $\begin{array}{l}\text { Cardiopulmonary failure, } \\
\text { cancer }\end{array}$ \\
\hline & $72 \pm 10$ & $8 \mathrm{M} / 8 \mathrm{~F}$ & & $520 \pm 314$ & $6.3 \pm 0.4$ & \\
\hline
\end{tabular}

Abbreviations: control (CTL), schizophrenia (SCZ), postmortem interval (PMI), female (F), male (M), no antipsychotic treatment within 6 weeks of death $(\mathrm{N})$, antipsychotic treatment within six weeks of death $(\mathrm{Y})$. Data presented as means \pm standard deviation.

TABLE II. Antibodies for Western studies

\begin{tabular}{|c|c|c|c|}
\hline Gene & Antibody & $\begin{array}{l}\text { Immunogen } \\
\text { species }\end{array}$ & Commercial source \\
\hline mGluR1 & $\begin{array}{l}\text { Rabbit polyclonal } \\
\text { anti-mGluR1a }\end{array}$ & rat* & $\begin{array}{l}\text { Chemicon International } \\
\text { (Temecula, CA) }\end{array}$ \\
\hline mGluR2 & $\begin{array}{c}\text { Rabbit polyclonal } \\
\text { anti-mGluR2/3 }\end{array}$ & human & $\begin{array}{l}\text { Upstate Biotechnology } \\
\text { (Lake Placid, NY) }\end{array}$ \\
\hline mGluR4 & $\begin{array}{c}\text { Rabbit polyclonal } \\
\text { anti-mGluR4a }\end{array}$ & rat* & Upstate Biotechnology \\
\hline mGluR5 & $\begin{array}{l}\text { Rabbit polyclonal } \\
\text { anti-mGluR5 }\end{array}$ & rat* & Upstate Biotechnology \\
\hline
\end{tabular}

*100\% homology with the human sequence.

sected, weighed, and homogenized (10\% W/V) in $50 \mathrm{mM}$ Tris-HCl ( $\mathrm{pH}$ 7.0) for 30 sec with a polytron homogenizer. The total protein concentration was determined by the Bradford method (Bradford, 1976). The homogenates were stored in $0.5-\mathrm{ml}$ aliquots at $-80^{\circ} \mathrm{C}$. For each antibody, gels were run and the blots were probed at the same time under identical conditions. The samples were prepared by combining homogenate with sample buffer $(62.5 \mathrm{mM}$ Tris-HCl, $20 \%$ glycerol, $2 \%$ sodium dodecyl sulfate, $5 \% \beta$-mercaptoethanol, $\mathrm{pH}$ 6.8) and heating at $95^{\circ} \mathrm{C}$ for $4 \mathrm{~min}$. Using the Mini-Protean II Slab Cell SDS PAGE system (Bio-Rad, Hercules, CA), 7\% polyacrylamide gels were prepared (7\% acrylamide/bisacryamide, $10 \%$ SDS, $12.5 \mu \mathrm{l}$ TEMED/ $25 \mathrm{ml}, 10 \%$ ammonium persulfate in $1.5 \mathrm{M}$ Tris- $\mathrm{HCl}, \mathrm{pH} 8.8$ ) and $40 \mu \mathrm{g}$ of protein homogenate was loaded in duplicate and run in SDS/ Tris/glycine buffer (25 mM Tris-HCl, 192 mM glycine,
$0.1 \%$ SDS, $\mathrm{pH} 8.3$ ) at $100 \mathrm{mV}$ for about $1 \mathrm{~h}$. Following transblotting to nitrocellulose membrane in Tris-glycine buffer (25 mM Tris, $192 \mathrm{mM}$ glycine, $\mathrm{pH}$ 8.3), blots were blocked with $3 \%$ milk (in case of antimGluR4a, 5\% milk) in phosphate-buffered saline (PBS) and agitated at $4{ }^{\circ} \mathrm{C}$ overnight with rabbit polyclonal antibodies $(1 \mu \mathrm{g} / \mathrm{ml}$ primary antibody in $3 \%$ milk in PBS) (Table II).

Next, blots were washed in distilled water and incubated with secondary antibody (horseradish peroxidase coupled donkey antirabbit immunoglobulin; Amersham, Piscataway, NJ) for $1.5 \mathrm{~h}$ on a shaker at room temperature. After four additional washes, enhanced chemiluminescence (ECL; Amersham) was used for detection of immunoreactivity. Blots were saturated with the ECL reagent, covered in Saran wrap, and exposed to ECL film (Amersham). The films were developed and digitally captured with a 

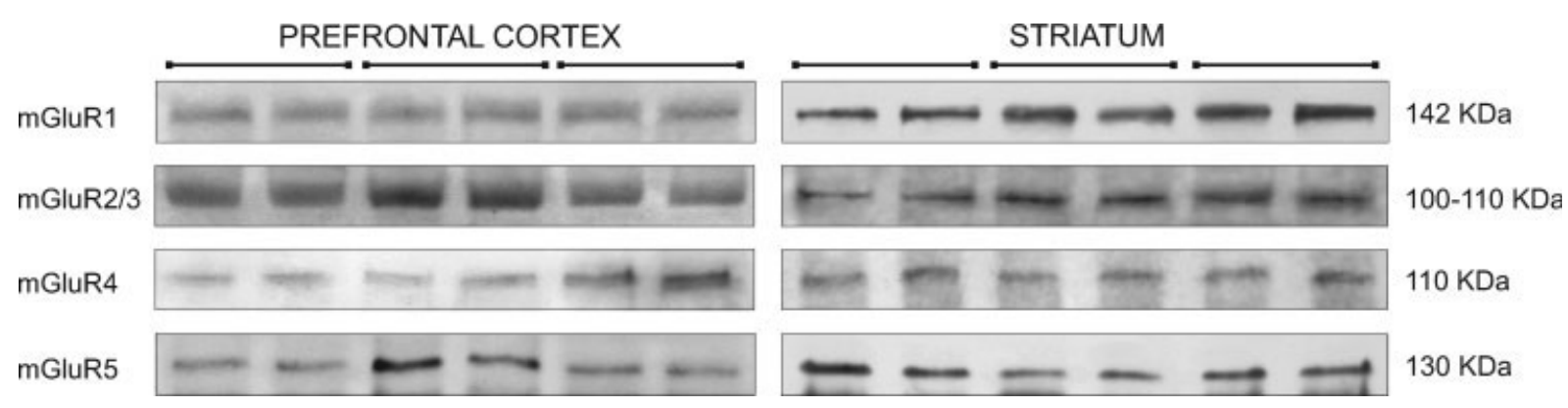

Fig. 1. Representative Western blot analysis of mGluR1a, mGluR2/3, mGluR4a, and mGluR5 protein in the prefrontal cortex (BA9) and striatum (nucleus accumbens). Data shown are from three different subjects run in duplicate.

Macintosh-based CCD imaging system with $\mathrm{NIH}$ Image 1.6. Gray scale values were obtained for protein bands detected by ECL at the expected molecular weight, membrane background was subtracted, and the adjusted gray scale values from duplicate samples in adjacent lanes were averaged and converted to optical density (O.D.).

\section{Stastistical analysis}

Statistical analysis was performed with Statistica (StatSoft, Tulsa, OK). The gender distribution between the two groups did not significantly differ $\left(\chi^{2}=2.2, P>0.05\right)$. In addition, there were no differences in $\mathrm{pH}$, age, or postmortem interval (PMI) between the schizophrenic and control groups. We used regression analysis to assess the potential confounding effects of following variables: age at death, PMI, and tissue $\mathrm{pH}$. When significant correlations were detected we used multivariate analysis of covariance (ANCOVA) to account for effects of covariates on mGluR expression. Otherwise, we used multivariate analysis of variance (ANOVA), followed by Tukey's HSD, when appropriate. We performed eight primary analyses, using subregion and diagnosis as independent variables and mGluR protein expression as the dependent variable. For all tests $\alpha=0.05$.

\section{RESULTS}

We detected mGluR1a, mGluR2/3, mGluR4a, and mGluR5 immunoreactivity in BA 9, 11, 32, and 46 as well as caudate, putamen, and nucleus accumbens. Representative Western blots for BA 9 and the nucleus accumbens are shown in Figure 1.

\section{Group I mGluR protein expression Prefrontal cortex}

We did not find associations between age, PMI, or $\mathrm{pH}$ and mGluR1a immunoreactivity. We detected a main effect for diagnosis $(\mathrm{F}(1,75)=4.13, P<0.04)$ and region $(\mathrm{F}(3,75)=29.8, P<0.01)$, but not a diagnosis by region interaction $(\mathrm{F}(3,75)=0.64, P>0.5)$ for increased mGluR1a expression (Fig. 2A). Post-hoc analyses showed that mGluR1a expression was significantly lower in BA46 than in BA11 $(P<0.01)$, BA32 $(P<0.01)$, and BA9 $(P<0.02)$.

We did not find an association between age or $\mathrm{pH}$ and mGluR5 expression (Fig. 2B). PMI was positively correlated with mGluR5 levels in the PFC $(\mathrm{r}=0.52$, $P<0.05)$. ANCOVA with PMI as a covariate showed a main effect for region $(\mathrm{F}(3,74)=19.33, P<0.01)$, but not for diagnosis $(\mathrm{F}(1,74)=1.07, P>0.30)$ or diagnosis by region interaction $(\mathrm{F}(3,74)=0.22, P>$ 0.88 ) for mGluR5 expression. mGluR5 expression was significantly lower in BA32 than in BA9 $(P<0.02)$ and BA46 $(P<0.01)$.

\section{Striatum}

We found a negative correlation between PMI and mGluR1a levels in the striatum $(\mathrm{r}=0.55, P<0.01)$. We did not find associations between age or $\mathrm{pH}$ and mGluR1a levels in striatum. We found a main effect for region $(\mathrm{F}(1,54)=11.83 P<0.01)$ but not for diagnosis $(\mathrm{F}(1,54)=1.504, P>0.22)$ or diagnosis by region interaction mGluR1a $(\mathrm{F}(2,54)=1.073 P>$ 0.34 ) for striatal expression of mGluR1a with PMI as a covariate (Fig. 2C). Post-hoc tests showed that the expression levels of mGluR1a are significantly lower in the putamen compared to the caudate nucleus $(P<$ $0.01)$ and nucleus accumbens $(P<0.01)$.

We did not find associations between age, PMI, or $\mathrm{pH}$ and striatal levels of mGluR5. We found a main effect for region $(\mathrm{F}(2,53)=8.40 P<0.01)$ but not for diagnosis $(\mathrm{F}(1,53)=0.69, P>0.41)$ or region by diagnosis interaction $(\mathrm{F}(2,53)=0.016 P>0.98)$ for mGluR5 expression (Fig. 2D). The expression of mGluR5 was significantly higher in putamen than in caudate nucleus $(P<0.01)$ and nucleus accumbens $(P<0.01)$.

\section{Group II mGluR protein expression Prefrontal cortex}

We did not find an association between age, $\mathrm{pH}$, or PMI and mGluR2/3 protein expression. We found 

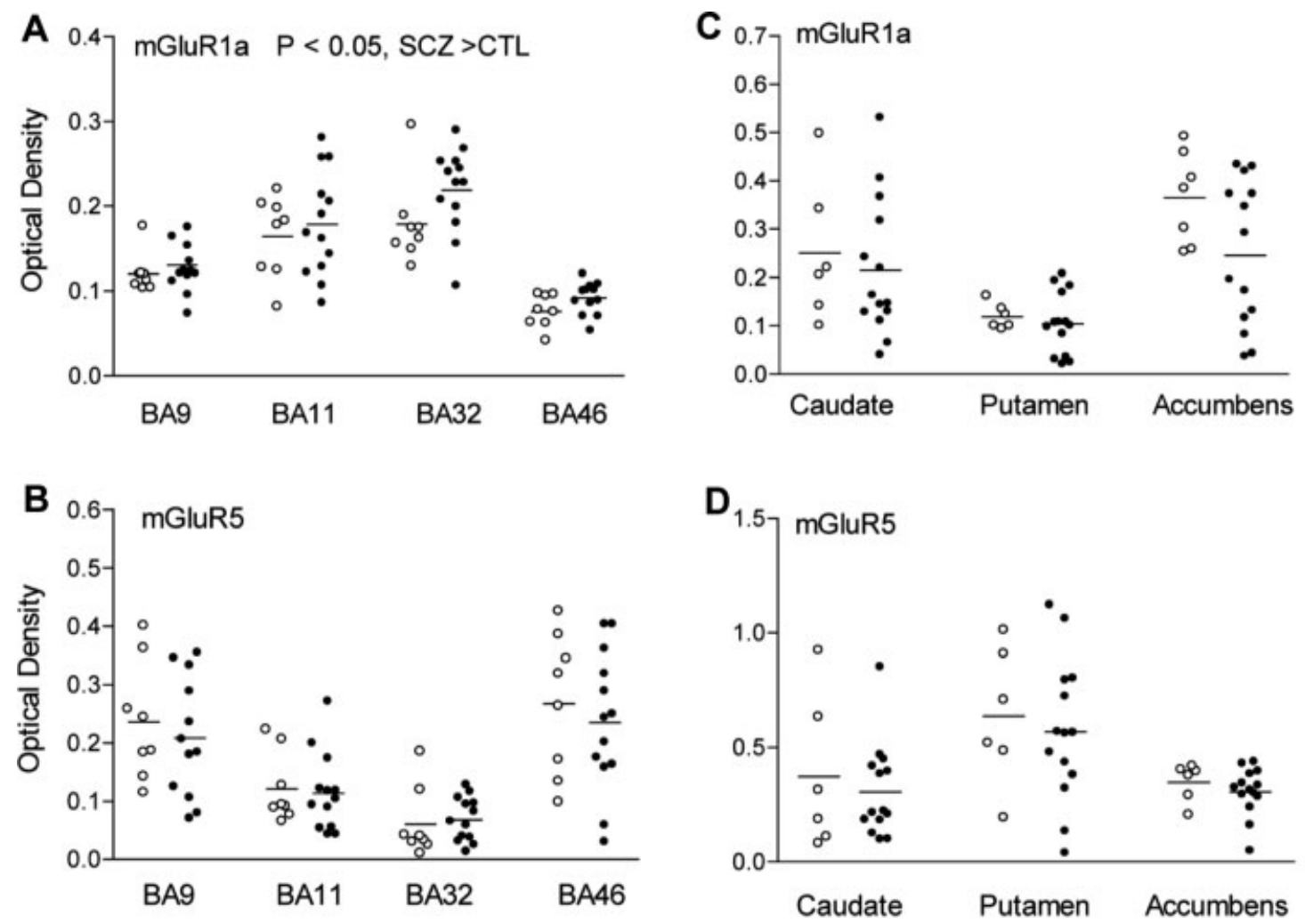

Fig. 2. Western blot analysis of mGluR1a (A,C) and mGluR5 (B,D) protein expression in the prefrontal cortex $(\mathbf{A}, \mathbf{B})$ and striatum $(\mathbf{C}, \mathbf{D})$ in schizophrenia and a comparison group. mGluR1a immunoreactivity was significantly increased in subjects with schizophrenia (SCZ) compared to controls (CTL) across Brodmann areas (BA) 9, 11, 32, and 46 .
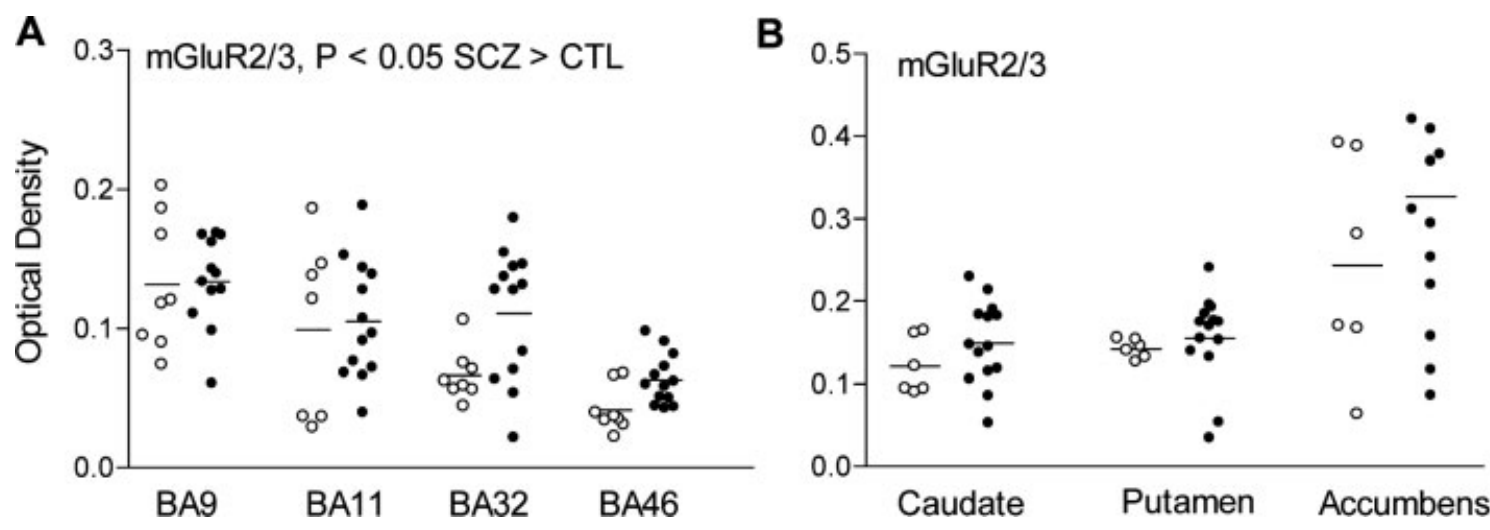

Fig. 3. Western blot analysis of mGluR2/3 protein expression in the prefrontal cortex (A) and striatum (B) in schizophrenia and a control group. mGluR2/3 immunoreactivity was significantly increased in subjects with schizophrenia (SCZ) compared to controls (CTL) across Brodmann areas (BA) $9,11,32$, and 46.

main effects for diagnosis $(\mathrm{F}(1,74)=4.5, P<0.037)$ and region $(\mathrm{F}(3,74)=14.7, P<0.01)$ but not for diagnosis by region interaction $(\mathrm{F}(3,74)=1.22, P>$ 0.30 ) for increased mGluR2/3 expression in PFC (Fig. 3A). Post-hoc tests showed that mGluR2/3 expression in BA 46 was significantly lower than in BA9 $(P<0.01)$, BA $32(P<0.01)$, and BA 11 $(P<0.01)$.

\section{Striatum}

We found no associations between age, $\mathrm{pH}$, or PMI and mGluR2/3 levels in the striatum. We found a main effect for region $(\mathrm{F}(1,52)=13.95, P<0.01)$ but not diagnosis $(\mathrm{F}(1,52)=2.59, P>0.11)$ or diagnosis by region interaction $(\mathrm{F}(1,52)=0.69, P>0.50)$ (Fig. 3B). Post-hoc analysis showed that mGluR2/3 expression is significantly higher in nucleus accum- 

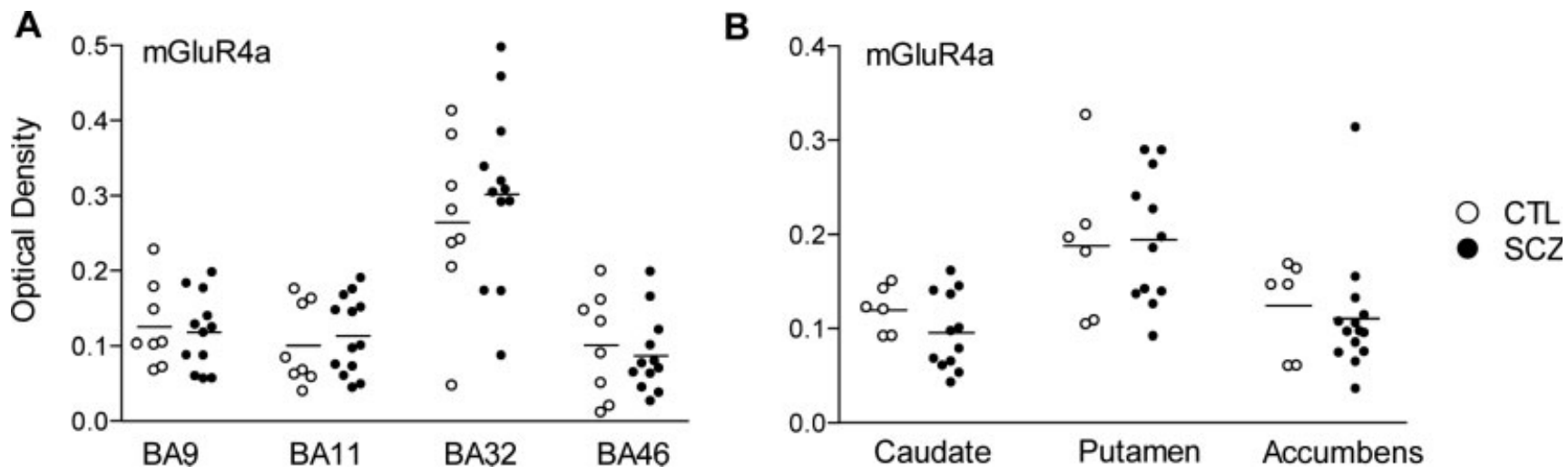

Fig. 4. Western blot analysis of mGluR4a protein expression in the prefrontal cortex (A) and striatum (B) in schizophrenia and a control group. Schizophrenia (SCZ), controls (CTL), Brodmann area (BA).

bens than caudate nucleus $(P<0.01)$ and putamen $(P<0.01)$.

\section{Group III mGluR protein expression Prefrontal cortex}

We found an association between age and mGluR4a expression in the PFC $(\mathrm{r}=0.56, P<0.05)$. Using age as a covariate, we found a main effect for region $(\mathrm{F}(1,72)=29.6, P<0.01)$ but not diagnosis $(\mathrm{F}(1,72)=$ $0.054, P>0.81)$ or region by diagnosis interaction $(\mathrm{F}(3,72)=0.450, P>0.71)$ (Fig. 4A). Post-hoc tests showed that mGluR4a expression was significantly higher in BA32 than in BA9 $(P<0.01)$, BA11 $(P<$ $0.01)$, and BA46 $(P<0.01)$.

\section{Striatum}

We did not find associations between age, $\mathrm{pH}$, or PMI and striatal mGluR4a levels. We found a main effect for region $(\mathrm{F}(2,50)=9.65, P<0.01)$ but not for diagnosis $(\mathrm{F}(1,50)=0.37, P>0.54)$ or region by diagnosis interaction $(\mathrm{F}(2,50)=0.28, P>0.75)$ for striatal mGluR4a expression (Fig. 4B). Post-hoc analysis showed significantly higher expression of mGluR4a in the putamen as compared to caudate nucleus $(P<$ $0.01)$ and nucleus accumbens $(P<0.01)$.

\section{Summary of results}

We found increased expression of mGluR1a and mGluR2/3, but not mGluR4a or mGluR5, in PFC in schizophrenia (Figs. 2, 3). In contrast to the findings in the prefrontal cortex, we did not find changes in striatal expression of any of the mGluRs we examined in schizophrenia.

\section{DISCUSSION}

We found significant increases in mGluR1a and mGluR2/3 protein in several areas of the PFC in schizophrenia (Figs. 2A, 3A). These findings are con- sistent with a previous report of increased group I mGluR expression in this illness (Ohnuma et al., 1998). Transcripts for mGluR5, but not mGluR3, were increased in neurons in BA11 in schizophrenia. Other studies have not detected changes in mGluR expression. mGluR5 mRNA was decreased in schizophrenia in the parahippocampal gyrus, while another group did not find any changes in group II mGluR protein expression in BA46 in this illness (Crook et al., 2002; Ohnuma et al., 1998, 2000). While the balance of these studies suggest that it is unclear if there are abnormalities of mGluR expression in the PFC in schizophrenia, our data support the hypothesis that mGluR expression in the PFC is abnormal in this illness.

In contrast to the PFC, mGluR expression has not previously been examined in the striatum in schizophrenia. We did not detect any changes in mGluR protein expression in this region. However, there are several studies that suggest abnormal glutamate transmission in the striatum in schizophrenia, including findings of decreased D-aspartate (a marker for high-affinity glutamate uptake sites) in the putamen, increased AMPA receptor binding in caudate nucleus, increased NMDA receptor density in putamen, and decreased excitatory amino acid transporter 3 transcript expression in the striatum (Aparicio-Legarza et al., 1998; McCullumsmith and Meador-Woodruff, 2002; Noga et al., 1997; Simpson et al., 1998). Thus, while there are some abnormalities of proteins associated with glutamate transmission in the striatum in schizophrenia, our findings suggest they do not include changes in mGluR expression.

The cellular expression pattern and specific functions attributed to different groups of mGluRs provide a basis for interpreting our results of increased mGluR1a and mGluR2/3 protein expression in schizophrenia. Previous studies have demonstrated mGluR1a labeling in the spines and dendrites of pyramidal cells and interneurons, indicating a post- 
synaptic localization of mGluR1a in the PFC (Muly et al., 2003). Increased mGluR1a protein expression in schizophrenia may be attributed to pyramidal cells, interneurons, or both, and there are data implicating alterations in both of these cell types in the PFC in this illness. While the techniques used in this study do not permit us to attribute increases in mGluR1a expression to one of these populations of cells, our findings are consistent with previous reports of abnormalities of cortical neurons in schizophrenia, as well as the functional roles of mGluRs in the glutamate synapse. Activation of postsynaptic mGluR1a may depolarize cell membranes, increasing the excitability of neurons. Localized postsynaptic depolarization by mGluRs contributes to removal of the $\mathrm{Mg}^{++}$block of NMDA receptors, promoting NMDA receptor activation. Interestingly, mGluR1a is associated with NMDA receptors in the postsynaptic density (PSD), and several molecules have been identified that promote colocalization of these receptors in the PSD (Husi et al., 2000). Since the glutamate hypothesis of schizophrenia includes NMDA receptor hypofunction as a primary pathophysiological lesion, an increase in mGluR1a could be interpreted as a compensatory response to diminished NMDA receptor function in this illness.

In contrast to postsynaptic expression of mGluR1a, mGluR2/3 immunostaining is predominately presynaptic (Petralia et al., 1996). An increase in presynaptic expression of mGluR2/3 in schizophrenia may lead to a decrease in glutamate release and/or an increase in glutamate reuptake, since mGluR2 and mGluR3 regulate these activities. A decrease in synaptic glutamate levels is consistent with both a decrease in NMDA receptor activation in the $\mathrm{PFC}$ and previous findings of hypofrontality in schizophrenia.

We found increases in both mGluR1a and mGluR2/ 3 in the PFC in schizophrenia. Since mGluR1a and mGluR2/3 may enhance and attenuate synaptic transmission, respectively, these findings argue against the conclusion that mGluR modulation of synaptic transmission is regulated in a simplistic manner (Hubert et al., 2001). However, there are several possible explanations that reconcile concomitant increases in protein expression for these receptors. Changes in mGluR1a and mGluR2/3 protein expression may occur in different types of synapses. For example, if increases in mGluR1a were limited to synapses comprised of glutamatergic synapses on postsynaptic GABAergic neurons, an increase in mGluR-mediated NMDA receptor activity would increase intrinsic inhibitory transmission in the PFC. Such an alteration would be consistent with an increase in presynaptic mGluR2/3 protein expression, which may also decrease excitatory neurotransmission by decreasing release or increasing reuptake of glutamate. On the other hand, changes in mGluR1a and
mGluR2/3 may be present in the same synapses. In this instance, an abnormality of the normally tightly regulated coordination of synaptic transmission might result in disparate compensatory responses, where regulation of activities such as glutamate release by presynaptic neurons or glutamate reuptake by astrocytes are not properly coupled to regulation of the postsynaptic neuron.

There are several potential limitations of this study. We performed a secondary analysis of mGluR expression in unmedicated vs. medicated subjects with schizophrenia, and did not detect any significant changes in mGluR expression between these groups. However, since only four out of 12 of our subjects in the group with schizophrenia were medication free for at least 6 weeks at the time of death, this secondary analysis is underpowered to detect changes in mGluR expression. In one previous report there were no changes in mGluR2, mGluR3, mGluR5, or mGluR7 transcript expression in rat frontal cortex following 21 days of treatment with haloperidol $(1 \mathrm{mg} / \mathrm{kg}$ ) (Tascedda et al., 2001). Although these results suggest that our findings of increased mGluR1 and mGluR2/3 protein expression in the $\mathrm{PFC}$ in schizophrenia may not be the result of a medication effect, the older schizophrenics in our study have higher lifetime exposures to neuroleptic medications, compared to subjects in younger cohorts, possibly amplifying effects attributable to antipsychotic medications. Thus, since the effects of chronic antipsychotic treatment on mGluR expression are not known, the possibility remains that our findings of increased group I and group II mGluR expression in the PFC in schizophrenia are secondary to antipsychotic treatment.

Another concern is that we studied aged individuals, a potential limitation of this collection as compared to those studied from other brain banks. Although the current study is significant for increased expression of mGluR2/3 and mGluR1a in an aged schizophrenic population, such findings may not be present in a younger group of patients, suggesting that the changes we have detected by and large represent the later stages of this illness. In fact, the study by Crook et al. (2002) that did not detect any changes in cellular localization or laminar distribution of mGluR2/3 protein in BA46 was done in a younger group of patients. However, the advanced age of our subjects may be a strength of this cohort; the subjects are free from comorbid traits such as suicide and substance abuse that confound many younger cohorts, have a predominance of negative symptomatology and cognitive impairment commonly found in the later stages of this illness, thus providing an enriched, more homogenous sample, and are rigorously characterized antemortem providing a level of reliability of diagnostic and demographic variables that are difficult to achieve in this field (Perl et al., 2000). 
Only nine control subjects were included in this cohort, potentially limiting the power of our study to detect significant changes. In addition, since we measured mGluR protein expression in brain homogenates, our findings only indicate whether or not there was a change in total mGluR protein expression and do not specify the type of cell or synapse where mGluR expression is altered. Finally, changes in protein expression do not necessarily indicate a change in receptor function. There may also be changes in mGluR surface expression, localization to the proper region of the plasma membrane, or linkage to intracellular signaling machinery.

\section{CONCLUSIONS}

Our findings of increased expression of mGluR1a and mGluR2/3 protein in the PFC suggest that mGluR activity may be increased in schizophrenia. Such an alteration in mGluR activity might alter synaptic plasticity, since the affected mGluR isoforms modulate several activities critical for normal synaptic transmission, including postsynaptic membrane excitability, glutamate release, and glutamate reuptake. Our data suggest that the glutamate hypothesis of schizophrenia includes abnormalities of mGluR expression and support modulation of mGluR activity as a target for pharmacological intervention in this devastating illness.

\section{REFERENCES}

Aparicio-Legarza MI, Davis B, Hutson PH, Reynolds GP. 1998. Increased density of glutamate/N-methyl-D-aspartate receptors in putamen from schizophrenic patients. Neurosci Lett 241:143-146.

Aronica E, van Vliet EA, Mayboroda OA, Troost D, da Silva FH, Gorter JA. 2000. Upregulation of metabotropic glutamate receptor subtype mGluR3 and mGluR5 in reactive astrocytes in a rat model of mesial temporal lobe epilepsy. Eur J Neurosci 12:23332344.

Aronica E, Gorter JA, Ijlst-Keizers H, Rozemuller AJ, Yankaya B, Leenstra S, Troost D. 2003. Expression and functional role of mGluR3 and mGluR5 in human astrocytes and glioma cells: opposite regulation of glutamate transporter proteins. Eur J Neurosci 17:2106-2118

Bradford MM. 1976. A rapid and sensitive method for the quantitation of microgram quantities of protein utilizing the principle of protein-dye binding. Anal Biochem 72:248-254.

Bradley SR, Standaert DG, Levey AI, Conn PJ. 1999a. Distribution of group III mGluRs in rat basal ganglia with subtype-specific antibodies. Ann N Y Acad Sci 868:531-534.

Bradley SR, Standaert DG, Rhodes KJ, Rees HD, Testa CM, Levey AI, Conn PJ. 1999b. Immunohistochemical localization of subtype 4a metabotropic glutamate receptors in the rat and mouse basal ganglia. J Comp Neurol 407:33-46.

Braff DL, Geyer MA. 1990. Sensorimotor gating and schizophrenia. Human and animal model studies. Arch Gen Psychiatry 47:181188.

Bunney WE, Bunney BG. 2000. Evidence for a compromised dorsolateral prefrontal cortical parallel circuit in schizophrenia. Brain Res Brain Res Rev 31:138-146.

Cauli B, Porter JT, Tsuzuki K, Lambolez B, Rossier J, Quenet B, Audinat E. 2000. Classification of fusiform neocortical interneurons based on unsupervised clustering. Proc Natl Acad Sci U S A 97:6144-6149.

Chen Q, He G, Wu S, Xu Y, Feng G, Li Y, Wang L, He L. 2005. A case-control study of the relationship between the metabotropic glutamate receptor 3 gene and schizophrenia in the Chinese population. Schizophr Res 73:21-26.
Chowdari KV, Mirnics K, Semwal P, Wood J, Lawrence E, Bhatia T, Deshpande SN, Ferrell RE, Middleton FA, Devlin B, Levitt P, Lewis DA, Nimgaonkar VL. 2002. Association and linkage analyses of RGS4 polymorphisms in schizophrenia. Hum Mol Genet 11:1373-1380.

Clinton SM, Meador-Woodruff JH. 2004. Thalamic dysfunction in schizophrenia: neurochemical, neuropathological, and in vivo imaging abnormalities. Schizophr Res 69:237-253.

Clinton SM, Haroutunian V, Davis KL, Meador-Woodruff JH. 2003. Altered transcript expression of NMDA receptor-associated postsynaptic proteins in the thalamus of subjects with schizophrenia. Am J Psychiatry 160:1100-1109.

Conn PJ, Pin JP. 1997. Pharmacology and functions of metabotropic glutamate receptors. Annu Rev Pharmacol Toxicol 37:205-237.

Crook JM, Akil M, Law BC, Hyde TM, Kleinman JE. 2002. Comparative analysis of group II metabotropic glutamate receptor immunoreactivity in Brodmann's area 46 of the dorsolateral prefrontal cortex from patients with schizophrenia and normal subjects. Mol Psychiatry 7:157-164.

Dean B, Hussain T. 2001. Studies on dopaminergic and GABAergic markers in striatum reveals a decrease in the dopamine transporter in schizophrenia. Schizophr Res 52:107-114.

Devon RS, Anderson S, Teague PW, Muir WJ, Murray V, Pelosi AJ, Blackwood DH, Porteous DJ. 2001. The genomic organisation of the metabotropic glutamate receptor subtype 5 gene, and its association with schizophrenia. Mol Psychiatry 6:311-314.

Egan MF, Straub RE, Goldberg TE, Yakub I, Callicott JH, Hariri AR, Mattay VS, Bertolino A, Hyde TM, Shannon-Weickert C, Akil M, Crook J, Vakkalanka RK, Balkissoon R, Gibbs RA, Kleinman JE, Weinberger DR. 2004. Variation in GRM3 affects cognition, prefrontal glutamate, and risk for schizophrenia. Proc Natl Acad Sci U S A 101:12604-12609.

Fujii Y, Shibata H, Kikuta R, Makino C, Tani A, Hirata N, Shibata A, Ninomiya H, Tashiro N, Fukumaki Y. 2003. Positive associations of polymorphisms in the metabotropic glutamate receptor type 3 gene (GRM3) with schizophrenia. Psychiatr Genet 13:7176.

Gill SS, Pulido OM, Mueller RW, McGuire PF. 1999. Immunochemical localization of the metabotropic glutamate receptors in the rat heart. Brain Res Bull 48:143-146.

Goff DC, Coyle JT. 2001. The emerging role of glutamate in the pathophysiology and treatment of schizophrenia. Am J Psychiatry 158:1367-1377.

Healy DJ, Haroutunian V, Powchik P, Davidson M, Davis KL, Watson SJ, Meador-Woodruff JH. 1998. AMPA receptor binding and subunit mRNA expression in prefrontal cortex and striatum of elderly schizophrenics. Neuropsychopharmacology 19:278-286.

Hsiao MC, Lin KJ, Liu CY, Tzen KY, Yen TC. 2003. Dopamine transporter change in drug-naive schizophrenia: an imaging study with 99mTc-TRODAT-1. Schizophr Res 65:39-46.

Hubert GW, Paquet M, Smith Y. 2001. Differential subcellular localization of mGluR1a and mGluR5 in the rat and monkey substantia nigra. J Neurosci 21:1838-1847.

Husi H, Ward MA, Choudhary JS, Blackstock WP, Grant SG. 2000. Proteomic analysis of NMDA receptor-adhesion protein signaling complexes. Nat Neurosci 3:661-669.

Kegeles LS, Shungu DC, Anjilvel S, Chan S, Ellis SP, Xanthopoulos E, Malaspina D, Gorman JM, Mann JJ, Laruelle M, Kaufmann CA. 2000. Hippocampal pathology in schizophrenia: magnetic resonance imaging and spectroscopy studies. Psychiatry Res 98:163175 .

Kosinski CM, Risso Bradley S, Conn PJ, Levey AI, Landwehrmeyer GB, Penney JrJB, Young AB, Standaert DG. 1999. Localization of metabotropic glutamate receptor 7 mRNA and mGluR7a protein in the rat basal ganglia. J Comp Neurol 415:266-284.

Mateos JM, Benâitez R, Elezgarai I, Azkue JJ, Lâazaro E, Osorio A, Bilbao A, Doänate F, Sarrâia R, Conquet F, Ferraguti F, Kuhn R, Knèopfel T, Grandes P. 2000. Immunolocalization of the mGluR1b splice variant of the metabotropic glutamate receptor 1 at parallel fiber-Purkinje cell synapses in the rat cerebellar cortex. J Neurochem 74:1301-1309.

McCullumsmith RE, Meador-Woodruff JH. 2002. Striatal excitatory amino acid transporter transcript expression in schizophrenia, bipolar disorder, and major depressive disorder. Neuropsychopharmacology 26:368-375.

Meador-Woodruff JH, Healy DJ. 2000. Glutamate receptor expression in schizophrenic brain. Brain Res Brain Res Rev 31:288-294.

Meador-Woodruff JH, Damask SP, Wang J, Haroutunian V, Davis KL Watson SJ. 1996. Dopamine receptor mRNA expression in human striatum and neocortex. Neuropsychopharmacology 15:17-29.

Meador-Woodruff JH, Haroutunian V, Powchik P, Davidson M, Davis KL, Watson SJ. 1997. Dopamine receptor transcript expres- 
sion in striatum and prefrontal and occipital cortex. Focal abnormalities in orbitofrontal cortex in schizophrenia. Arch Gen Psychiatry 54:1089-1095.

Meador-Woodruff JH, Davis KL, Haroutunian V, Mental Health Research I. 2001a. Abnormal kainate receptor expression in prefrontal cortex in schizophrenia. Neuropsychopharmacology 24:545-552.

Meador-Woodruff JH, Hogg AJ, Smith RE. 2001b. Striatal ionotropic glutamate receptor expression in schizophrenia, bipolar disorder and major depressive disorder. Brain Res Bull 55:631-640.

Meador-Woodruff JH, Clinton SM, Beneyto M, McCullumsmith RE. 2003. Molecular abnormalities of the glutamate synapse in the thalamus in schizophrenia. Ann N Y Acad Sci 1003:75-93.

Mueller HT, Meador-Woodruff JH. 2004. NR3A NMDA receptor subunit mRNA expression in schizophrenia, depression and bipolar disorder. Schizophrenia Res 71:361-370

Mueller HT, Haroutunian V, Davis KL, Meador-Woodruff JH. 2004. Expression of the ionotropic glutamate receptor subunits and NMDA receptor-associated intracellular proteins in the substantia nigra in schizophrenia. Brain Res Mol Brain Res 121:60-69.

Muly EC, Maddox M, Smith Y. 2003. Distribution of mGluR1alpha and mGluR5 immunolabeling in primate prefrontal cortex. J Comp Neurol 467:521-535.

Nakanishi S. 1992. Molecular diversity of glutamate receptors and implications for brain function. Science 258:597-603.

Nakanishi S. 1994. Metabotropic glutamate receptors: synaptic transmission, modulation, and plasticity. Neuron 13:1031-1037.

Nakanishi S, Nakajima Y, Masu M, Ueda Y, Nakahara K, Watanabe D, Yamaguchi S, Kawabata S, Okada M. 1998. Glutamate receptors: brain function and signal transduction. Brain Res Brain Res Rev 26:230-235.

Noga JT, Hyde TM, Herman MM, Spurney CF, Bigelow LB, Weinberger DR, Kleinman JE. 1997. Glutamate receptors in the postmortem striatum of schizophrenic, suicide, and control brains. Synapse 27:168-176.

Ohnuma T, Augood SJ, Arai H, McKenna PJ, Emson PC. 1998 Expression of the human excitatory amino acid transporter 2 and metabotropic glutamate receptors 3 and 5 in the prefrontal cortex from normal individuals and patients with schizophrenia. Brain Res Mol Brain Res 56:207-217.

Ohnuma T, Tessler S, Arai H, Faull RL, McKenna PJ, Emson PC. 2000. Gene expression of metabotropic glutamate receptor 5 and excitatory amino acid transporter 2 in the schizophrenic hippocampus. Brain Res Mol Brain Res 85:24-31.

Perl DP, Good PF, Bussiáere T, Morrison JH, Erwin JM, Hof PR 2000. Practical approaches to stereology in the setting of agingand disease-related brain banks. J Chem Neuroanat 20:7-19.

Petralia RS, Wang YX, Niedzielski AS, Wenthold RJ. 1996. The metabotropic glutamate receptors, mGluR2 and mGluR3, show unique postsynaptic, presynaptic and glial localizations. Neuroscience 71:949-976

Pin JP, Duvoisin R. 1995. The metabotropic glutamate receptors: structure and functions. Neuropharmacology 34:1-26.

Simpson MD, Slater P, Deakin JF. 1998. Comparison of glutamate and gamma-aminobutyric acid uptake binding sites in frontal and temporal lobes in schizophrenia. Biol Psychiatry 44:423-427.

Tallaksen-Greene SJ, Kaatz KW, Romano C, Albin RL. 1998. Localization of mGluR1a-like immunoreactivity and mGluR5-like immunoreactivity in identified populations of striatal neurons. Brain Res 780:210-217.

Tascedda F, Blom JM, Brunello N, Zolin K, Gennarelli M, Colzi A, Bravi D, Carra S, Racagni G, Riva MA. 2001. Modulation of glutamate receptors in response to the novel antipsychotic olanzapine in rats. Biol Psychiatry 50:117-122.

Theberge J, Bartha R, Drost DJ, Menon RS, Malla A, Takhar J, Neufeld RW, Rogers J, Pavlosky W, Schaefer B, Densmore M, AlSemaan Y, Williamson PC. 2002. Glutamate and glutamine measured with 4.0 T proton MRS in never-treated patients with schizophrenia and healthy volunteers. Am J Psychiatry 159:1944-1946.

Weinberger DR, Egan MF, Bertolino A, Callicott JH, Mattay VS, Lipska BK, Berman KF, Goldberg TE. 2001. Prefrontal neurons and the genetics of schizophrenia. Biol Psychiatry 50: 825-844. 